\title{
Louis Edward Kirstein
}

Louis Edward Kirstein, a charter member of the Business Historical Society, died on December 10, 1942. The life of this Boston business man has a double significance, for not only was he a great merchant but he was also a great civic leader. ${ }^{1}$

Kirstein was an individual of positive personality and character. $\mathrm{He}$ was direct and gruff to the point of frightening on first meeting, but closer acquaintance revealed his fairness and his essentially generous and kind nature. He had great physical and nervous energy: he liked activity and the competitive drives of business, and he enjoyed the procedures that went into the conduct of business enterprise. A basic element in his success as merchant and citizen was his regard and liking for people. He was methodical in the extreme, exacting of himself and others, and impatient with' shoddy or sham. One who knew him well said of him: "He measured every man, hinself most of all, against the work to be done in this world."

Though he did not have much formal schooling, he had a receptive and inquiring mind which made him an educated man in the real sense of the term. He learned from his work, he read extensively-especially biography-and he drew richly from his friends and from people he met and the experiences he had in business and in public work. In his later years he talked much of two men who had influenced him greatly. One was James J. Storrow, an outstanding banker and civic leader of Boston, who gave Kirstein by example a high conception of the business man as a citizen. The other was Louis D. Brandeis, whom Kirstein came to know in his early days in Boston. This Boston attorney, who later became a member of the United States Supreme Court, talked much about the social responsibilities of the business man and helped Kirstein to see that business was a matter of human

1 For details of Kirstein's business and nonbusiness activities and connections, see Women's Wear Daily, December 10 and 11, 1942; also Boston Herald, December 11, 1942, and New York Times, December 11, 1942. 
relationships that were basically ethical. Brandeis and Kirstein's mother gave him an appreciation of his Jewish kinship and the richness of his Jewish heritage. Though not an easily articulate man, he was very much in demand as a speaker because he had something to say. The qualities of character which seem above everything else to have impressed those who knew him well were his high integrity and his great modesty.

Kirstein was a singularly successful man. He had a happy life with his family - his wife, Rose Stein Kirstein, and a daughter and two sons, in whom he found great satisfaction. One son followed the father's business; he became vice-president of Bloomingdale Brothers, of New York, before the war, from which position he was called to Washington to become executive secretary of the National War Labor Board. Kirstein's business ventures were profitable; he was generous in giving and he left a moderate fortune. Honorary degrees were conferred upon him by Harvard University and Boston University, and on his seventieth birthday friends established the Louis E. Kirstein Fellowship Fund at the Harvard Medical School in his honor. He had an unusual facility in making and keeping friends, and the high tribute paid to him on his death is a measure of the great esteem and respect that he had gained in his home city and throughout the nation.

Kirstein's father, Edward Kirstein, a liberal refugee from the Germany of 1848 , came to this country almost penniless. Beginning business as a pedlar, he built up a wholesale business in optical goods in Rochester, New York. There Louis Edward was born on July 9, 1867. His business career began when he left school at the age of thirteen to work as errand boy in a store. On his sixteenth birthday he ran away from home. After several years, in which he made some money in the business end of baseball, he returned home where he bought the Rochester Club, a member of the American Association, which had been established in 1882.

In 1890 Kirstein became a traveling salesman for his father's wholesale optical goods concern. This work took him to Boston where, in 1894, he became associated with Andrew J. Lloyd, a retailer who was a customer of the father's firm. Shortly thereafter he returned to Rochester and joined his brother in running the family's business. In 1901 he went on the road again, this time for his father-in-law's firm, Stein-Bloch Co., Rochester clothing manufacturers. 
While living in Boston, Kirstein had become acquainted with Edward A. and Lincoln Filene, whose father had established a retail store in Boston in the 1880's. In 1912, when William Filene's Sons Co. was undergoing a rapid expansion and a new corporation with increased capital was organized, Kirstein became associated with the firm as one of its vice-presidents, investing a substantial sum. In the next twenty years, Filene's was to grow from a relatively small establishment into one of the largest and most successful men's, women's, and children's specialty stores in the world.

In the development of Filene's, Kirstein shared with the Filene brothers and Edward J. Frost the administration of the business. Kirstein had charge of merchandising and publicity, but as a member of the management his influence came to pervade every phase of the life of the store. The operation of Filene's expanding business meant development in organization, policy, and management, while meeting the constant impact of change in general business conditions, in manufacturing and buying, and in consumer demand. It is possible here only to note some of the underlying policies which Kirstein followed in his work as a merchant.

Kirstein's emphasis was first and last on the customer. He held that the retailer as "purchasing agent for the public" had two functions: to find out what his customer wanted and to see that he got it. It was his policy in the development of his merchandise organization to stress constantly to his people the necessity of watching, closely, changing consumer demand, because he recognized the fact that buying habits were never constant for any period of time. In buying he looked for the newest in design and style-he criticized manufacturers for their absorption in the technical aspects of production and price to the neglect of what the customer wanted. He himself traveled the world over-he crossed the Atlantic nearly a hundred times-to look for merchandise. But he never forgot that his object was to buy what the public wanted and not what he thought it should have.

Kirstein's publicity was notable for its honesty at a time when that could not be said of much of the advertising of retail stores. A much-quoted "Kirsteinism" was that "advertising pays when it is believed." The rule of his publicity was: "No exaggeration, no misleading statement and no half truth shall be made under any circumstances in our publicity." In advertising he endeavored to 
publicize only that merchandise which was news. He believed in building up a steady volume of sales based on a reputation for always having on hand goods right in quality, design, and style; and, instead of constantly advertising unusual sales, he believed in maintaining a "bargain" department for distress and odd-lot merchandise, that pretended to be only what it really was.

Kirstein similarly stood for decency in the procurement of merchandise at a time when the market was intensely competitive and many large retailers were unscrupulous in their treatment of manufacturers. In order to be sure that the buyers did not take advantage of manufacturers in returning merchandise with which they were overstocked, Kirstein did a most unusual thing in insisting that every manufacturer receive a letter or card, with each return of merchandise, saying in part: "If for any reason you think this is contrary to Filene's policy of not making unjust returns, please advise us directing the letter attention of $\mathrm{Mr}$. Louis $\mathrm{E}$. Kirstein." The manufacturer was thereby encouraged to complain if he had just cause, although not many manufacturers did complain. Kirstein, himself, frequently examined the cause of complaints, and the responsible Filene buyer had to prove his case with respect to the return of the merchandise.

As a merchandising, man, Kirstein's influence came to be felt throughout the retailing industry, in which he came to be regarded as a national leader. Always active in various trade organizations, in the 1930's he saw the need for an organization which would represent all branches of retailing and was one of the founders of the American Retail Federation. He also became an enthusiastic supporter of better business bureaus and chambers of commerce.

Kirstein was often spoken of as an industrial statesman. Though he was never in charge of personnel in Filene's he enjoyed the respect and confidence of the employees of the store-he maintained that the success of a store was "in the hands of the $\$ 15$ or $\$ 25$ young man or woman who stands behind your counter." In his work of purchasing uniforms for the government in World War I he made some good friends among labor leaders, particularly in the clothing industry, and he came in contact with cases of conflict between employer and employee. He won a reputation among labor and employers for good judgment, fairness, and integrity; he served on several important government agencies, including the Massachusetts Industrial Commission, the National 
Labor Board, and the Industrial Advisory Board under the NRA, and he was also much in demand for the private settlement of disputes. In his own industry he worked for the elimination of products of sweat-shop labor.

He urged upon management that labor relations should be considered as important in the formulation of administrative policy as finance, production, and distribution. He regarded the excesses of labor as the result of a sudden acquisition of power, and he believed that, if freely accepted by management and if met in a spirit of honesty and frankness, labor would come to understand better the problems of management. In recent years he pleaded for the minimizing of class conflict and for the strengthening of understanding and unity.

He early recognized the increasing rôle of the trade union. He thought the union was trying to do for labor what trade associations, chambers of commerce, and better business bureaus were trying to do for business. He felt that the social validity of all such organizations was their willingness to temper immediate selfinterest with long-range considerations of social welfare. When properly self-disciplined, such organizations might be the means of achieving an equilibrium between interrelated interests with the least possible government coercion.

An eminently successful business man, Kirstein was widely known for his participation in the work of charitable, philanthropic, and educational agencies. He looked upon his business as a public service, but that was not enough. From his early years in Boston, he took an active interest in public affairs. This was in a sense forced upon him in recognition of his administrative capacity and his generosity, but he accepted the responsibilities willingly. There was in him little of the sentimental desire to "do good;" he took on public responsibilities because it was good business to help develop a good community, because he recognized an obligation, to society, and, probably, because he himself got deep personal satisfaction out of the contacts made and the results achieved.

It is impossible here to catalog all his activities. Among Jewish organizations, local and national, he came to be an outstanding leader. He was a faithful worker for the Boston Community Fund. He believed that the aim of social work should be not merely to dole out help in emergencies but especially to aid people toward helping themselves. He assisted many young people to 
obtain an education. Hospitals he helped as a means to further community health. To no institution was he more faithful than to the Boston Public Library on whose board he long served; the library stood for democracy's faith in opportunities for the selfdevelopment and education of all its people, and he had a deep faith in democracy. To the city he gave a business library, the Edward Kirstein Memorial Library, in memory of his father. He was a faithful friend of the Harvard Graduate School of Business Administration which, according to one who knew him well, "embodied his conviction that business must become increasingly a profession if business men are to be entrusted with the custodianship of economic institutions in a civilization where life, work, and the pursuit of happiness are inextricably interwoven."

It was on this theme, the interrelations of business and society, that he especially dwelt in his later years. The depression of the 1930's, with its threat to business and to the social fabric, made him question the wisdom of the business man's devoting much of his energy to community affairs. ${ }^{2}$ The depression challenged the business man to see that his first responsibility to society was to make his own business healthy and strong, but Kirstein could not get away from the conviction that the business man's responsibilities, like his business itself, had wide ramifications. He found comfort in the past-he had experienced earlier periods of depression and many changes in business, and he knew that flux was the rule of the life of any society. He was convinced that America not only had to weather these difficult times but also had to correct the evils of maladjustment from overrapid economic growth. In a speech which he made in 1938 he gave three rules on how to proceed: (1) Cease witch-hunting and assume that the majority of the people are anxious to build a healthy and progressive society; (2) be willing to experiment; but (3) remember that all units in society are interrelated, and hence experiments must be thought through in advance from the point of view of the total structure as well as of the part immediately concerned.

Thus Louis E. Kirstein, a notably successful business administrator with a deep feeling for the wellbeing of society, looked with hope to the future. It is proper to ask whether his work and his business and social philosophy do not in themselves contain much that has value for the years that lie ahead.

2Louis E. Kirstein, "Mind Your Own Business," Atlantic Monthly, October, 1932, pp. 404-410. 